\title{
Особенности распределения палладия в массивных рудах Октябрьского месторождения (Норильский район)
}

\author{
Григорьева А.В., Служеникин С.Ф., Волков А.В.
}

Институт геологии рудных месторождений, петрографии, минералогии и геохимии РАН, Москва, grig357@таil.ru

\begin{abstract}
Аннотация. В массивных рудах Хараелахского интрузива Октябрьского месторождения установлена дифференциация массивных руд на преимущественно железистые (пирротиновые, пентландит-пирротиновые, халькопирит-пентландит-пирротиновые) и преимущественно медистые (халькопиритовые, талнахитовые, халькопирит-кубанитовые и их сочетания). Определено, что в железистых рудах палладий присутствует в виде твердого раствора в пентландите, а в медистых - в виде собственных минералов. Выполнено изучение распределения палладия в пентландите железистой разности массивной руды методом лазерной абляции с индуктивно-связанной плазмой (LA ICP-MS). Высокие содержания палладия в пентландите, показывают возможность его рентабельного извлечения из существенно железистых руд.

Ключевые слова: пентландит, минералы платиновой группы (МПГ), лазерная абляция с индуктивносвязанной плазмой.

\section{Features of palladium distribution in massive ores of the Oktyabrsky deposit (Norilsk district)}

Grigorieva A.V., Sluzhenikin S.F., Volkov A.V. Institute of Geology of Ore Deposits, Petrography, Mineralogy and Geochemistry of the Russian Academy of Sciences, Moscow,grig357@mail.ru

Abstract. In the massive ores of the Kharaelakh intrusive of the Oktyabrsky deposit, the differentiation of massive ores into mainly ferruginous (pyrrhotite, pentlandite-pyrrhotite, chalcopyrite-pentlandite-pyrrhotite) and mainly copper (chalcopyrite, talnachite, chalcopyrite-kubanite and their combinations) has been established. It is determined that in predominantly ferruginous ores, palladium is present as a solid solution in pentlandite, and in predominantly copper ores - in the form of its own minerals. The content and distribution of palladium in pentlandite of predominantly ferruginous ore was determined by laser ablation with inductively coupled plasma (LA ICP-MS). The high palladium content in pentlandite shows the possibility of its cost-effective extraction from substantially ferrous ores.
\end{abstract}

Key words: pentlandite, platinum group minerals (MPG), laser ablation with inductively coupled plasma.

Многие российские и зарубежные исследователи изучали уникальные медно-никелевые руды Норильских месторождений (Дистлер, 1985; Дистлер и др., 1988, 1999; Генкин и др., 1981; Налдретт, 2003; Служеникин, 2010). Они установили, что в большинстве магматических сульфидных месторождений элементы платиновой группы (ЭПГ) обнаруживаются как в структуре сульфидов цветных металлов: пирротина (Рo), пентландита (Pn), халькопирита (Ccp) и кубанита (Cbn), так и в виде минералов платиновой группы (МПГ). Руда, богатая пирротином (Ро), как полагают, представляет собой кумулят твердого раствора моносульфида (MSS) из исходной сульфидной жидкости, а руда, богатая Cср, представляет собой смесь фракционированной сульфидной жидкости и промежуточного твердого раствора (ISS) (Mansur et al., 2019).

В массивных рудах Хараелахского интрузива установлена минеральная и скрытая зональность, которая детально описана в работах (Генкин и др., 1981; Служеникин, 2010). Эта зональность выражается не только в закономерных изменениях минеральных парагенезисов, но и в изменении химического состава основных сульфидов и отражает дифференциацию этих руд на существенно железистые (приближающиеся к MSS), переходные и существенно медистые (ISS). Установлено, что богатые пирротином руды представляют собой скопления MSS и несовместимы с такими элементами, как платина, золото, серебро, а также теллур, мышьяк, висмут, сурьма, олово, обозначаемыми как TABS, которые уходят вместе с фракционированной жидкостью при кристаллизации рас- 
плава, в то время как часть палладия остается в MSS и выделяется затем в виде твердого раствора в пентландите.

$\mathrm{Pt}, \mathrm{Pd}, \mathrm{Au}, \mathrm{Ag}$, элементы TABS, Pb образуют повышенные концентрации в богатой медью руде и выделяются в ней в виде собственных минералов, часто в сростках их разнообразных минеральных форм между собой. В предлагаемой работе проведено исследование формы нахождения $\mathrm{Pd}$ в существенно железистых (по химическому составу близких к MSS) и существенно медистых (ISS) массивных рудах, выделяющихся в Хараелахском интрузиве Октябрьского месторождения и распределение содержания этого элемента в этих типах руд.

\section{Массивная руда с преобладанием железистых рудных минералов}

Для определения палладия в пентландите была выбрана массивная руда с глубины 1564 м, отобранная из рудного тела, расположенного на западном фланге Октябрьского месторождения (Хараелахский интрузив) с преобладающим содержанием пирротина, наиболее приближенная к MSS. Она представлена халькопирит-пентландит-пирротиновой разновидностью со следующим содержанием основных сульфидов: пирротин - 62.5 об. \%, пентландит - 20 об. \%, халькопирит - 15 об. \%,

В этой руде, по результатам ICP-MS, содержание Pd ниже порога определений, тем не менее, поскольку в руде содержится около 20 \% пентландита, который образует крупные выделения в полях развития пирротина, есть возможность определить содержание палладия, присутствующего в нем в виде твердого раствора. Определение содержания этого элемента в $\mathrm{Pn}$ и распределение его в этом минерале по профилю проведено с помощью масс-спектрометрии с лазерной абляционноиндуктивно связанной плазмой (рис. 1).
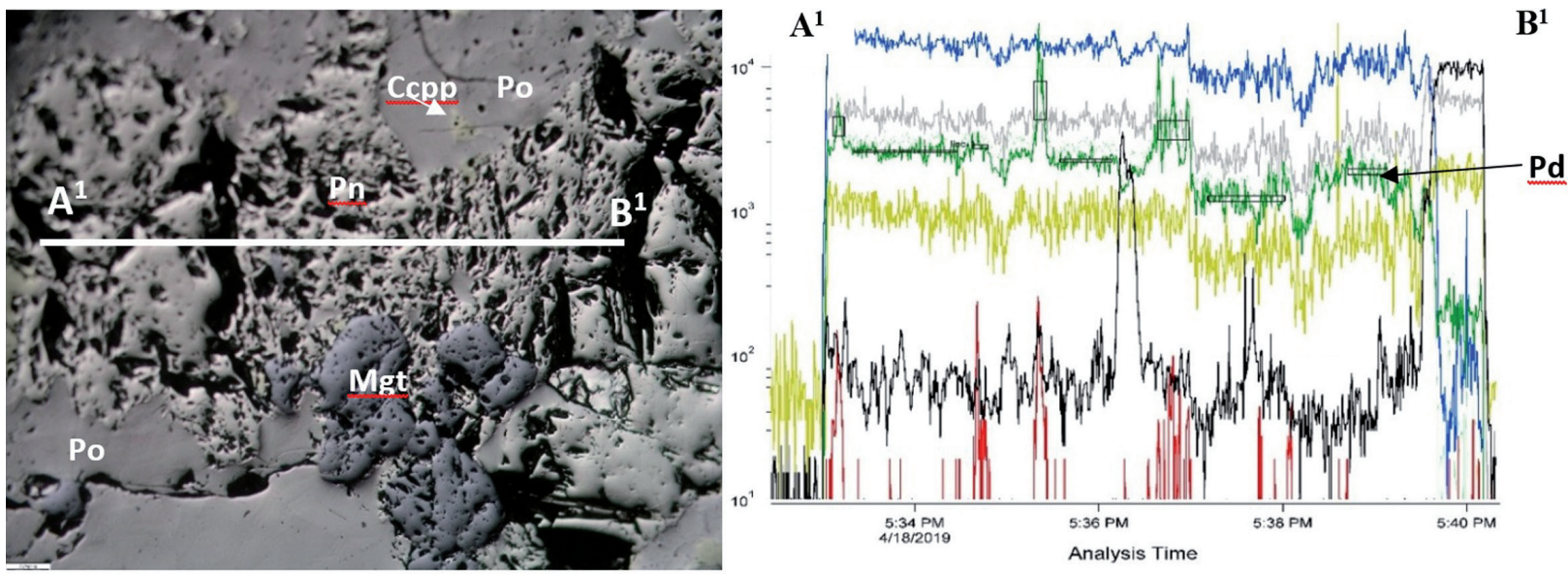

Рис. 1. А - пентландит в халькопирит-пирротиновой руде (Ро - пирротин; $\mathrm{Pn}$ - пентландит; Ср - халькопирит; $\mathrm{Mgt}$ - магнетит). Линия $\mathrm{A}^{1}-\mathrm{B}^{1}$ - профиль определений, длина около 2 см. Изображение в отраженном свете. В - интенсивность импульсов определяемых элементов.

Fig. 1. A - pentlandite in chalcopyrite-pyrrhotite ore (Po - pyrrhotite; Pn - pentlandite; Cp - chalcopyrite; $\mathrm{Mgt}$ - magnetite). Line $\mathrm{A}^{1}-\mathrm{B}^{1}$ - profile definition, the length is about $2 \mathrm{~cm}$. Image in reflected light. $\mathrm{B}$ - the intensity of the pulses of the detected elements.

Определено, что распределение содержания палладия по профилю, проведенному через крупное выделение (более 2 см) пентландита, расположенного в поле развития пирротина, неравномерно и изменяется в интервале от 131.6 до 327 ppm (среднее содержание 181.16 ррм или г/т). Следовательно, определение содержания палладия в пентландите дает возможность рассчитать его количество в концентрате и определить возможность его извлечения.

\section{Массивная руда с преобладанием медистых рудных минералов}

Руды, обогащенные медными сульфидами, концентрирующиеся в остаточном сульфидном растворе (ISS), содержат более высокие концентрации ЭПГ, а также более высокие концентрации теллура, мышьяка, висмута, сурьмы и олова, которые образуют с ЭПГ общие минеральные формы 
в этих рудах, выделяющиеся в медных сульфидах. Как пример массивной руды этого типа, была изучена массивная медистая руда, также отобранная на западном фланге Октябрьского месторождения, расположенная на глубине 1617.6 м, представленная пентландит-кубанит-халькопиритовой разновидностью. В ней преобладают рудные минералы группы халькопирита со следующим содержанием основных сульфидов: халькопирит - 80 об. \%, кубанит - 12 об. \%, пентландит - 5 об. \%. Содержания палладия в руде, определены методами РФА и ICP-MS, полученные результаты достаточно близки и составляют около 350 г/т. Методом рентгеновского микроанализа в образце этой руды были установлены минералы платиновой группы в ассоциации с золотом, серебром и галенитом $(\mathrm{PbS})$, выделяющиеся в поле развития минералов группы халькопирита.
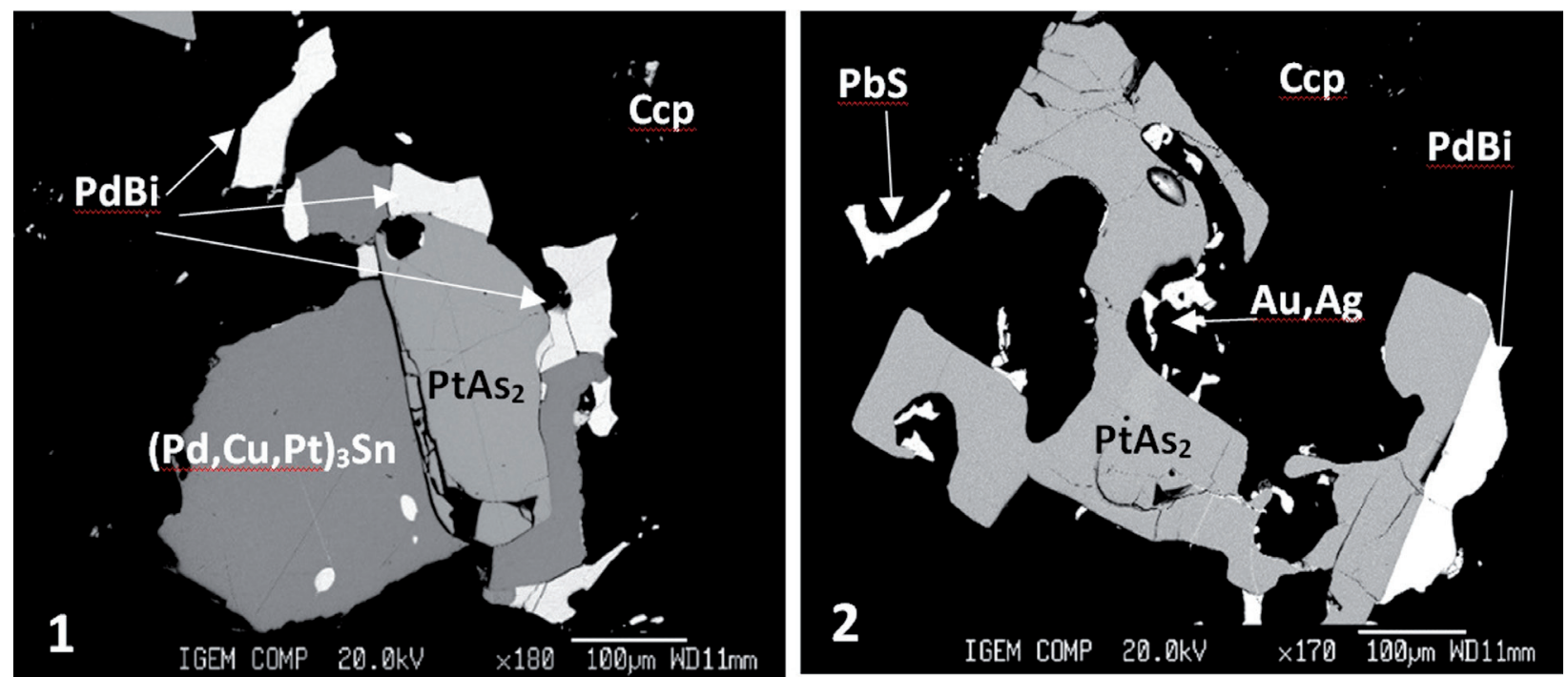

Рис. 2. Совместное выделение минералов платиновой группы (МПГ), $\mathrm{Au}$ и $\mathrm{Ag}$ в в кубанит-халькопиритовом агрегате массивной талнахитовой руды Октябрьского месторождения: 1 - полярит (РdBi) и станнопалладинит $\left((\mathrm{Pd}, \mathrm{Cu}, \mathrm{Pt})_{3} \mathrm{Sn}\right)$ в сростке со сперрилитом $\left(\mathrm{PtAs}_{2}\right) ; 2$ - полярит $(\mathrm{PdBi})$ в сростке со сперрилитом $\left(\mathrm{PtAs}_{2}\right)$ и в ассоциации с золото-серебрянными сплавами и галенитом $(\mathrm{PbS})$. Изображение в отраженных электронах.

Fig. 2. Joint isolation of platinum group minerals (MPG), Au,and Ag in the kubanite-chalcopyrite aggregate of the massive talnachite ore of the Oktyabrsky deposit: 1 - polarite $(\mathrm{PdBi})$ and stannopalladinite $((\mathrm{Pd}, \mathrm{Cu}, \mathrm{Pt}) 3 \mathrm{Sn})$ in the fusion with sperrilite (PtAs2); 2 - polarite (PdBi) in the fusion with sperrilite (PtAs2) and in association with gold-silver alloys and galenite $(\mathrm{PbS})$. Image in reflected electrons.

Установлено, что палладий образует собственные минералы с висмутом, оловом, сурьмой и свинцом. Кроме того, эти минералы находятся в ассоциации с золотом, серебром и галенитом (см. рис. 2). В массивной талнахитовой руде Октябрьского месторождения установлены минералы палладия со следующими обобщенными составами-станнопалладинит $\left(\mathrm{Pd}_{1.80-1.90} \mathrm{Pt}_{0.27-0.36} \mathrm{Cu}_{0.78-0.80}\right)_{2.95-3.04}$ $\left(\mathrm{Sn}_{0.93-0.99} \mathrm{Sb}_{0.05-0.11}\right)$; полярит $\left(\mathrm{Pd}_{0.94-0.96} \mathrm{Pt}_{0.02-0.03}\right)_{0.97-0.99}\left(\mathrm{Bi}_{0.96-1.03} \mathrm{~Pb}_{0.01-0.07} \mathrm{Sb}_{0.01}\right)_{1.01-1.03}$; минерал состава $\left(\mathrm{Pd}_{5.22-4.99} \mathrm{Cu}_{0.13-0.15}\right)_{5.12-5.37}\left(\mathrm{Sb}_{0.47-0.42} \mathrm{Sn}_{0.54-0.82} \mathrm{As}_{0.27-0.59}\right)_{1.63-1.88} ;$ соболевскит $\left(\mathrm{Pd}_{1.06}\left(\mathrm{Bi}_{0.84-0.88} \mathrm{Te}_{0.06-0.10}\right)_{0.94}\right)$.

Таким образом, определено содержание палладия в существенно железистой массивной руде, где он присутствует в форме твердого раствора в значительном количестве (в среднем около 180 г/т пентландита), что позволяет рассчитать его количество в концентрате и определить возможность и рентабельность его извлечения. Подтверждено присутствие $\mathrm{Pd}$ в существенно медистой руде, где он концентрируется в остаточном расплаве ISS, совместно с платиной и образует целый ряд собственных минералов в ассоциации с Pt и элементами TABS.

Работа выполнена при финансовой поддержке РФФИ (грант № 18-05-70001) «Изучение геологических и геодинамических обстановок формирования крупных месторождений стратегических металлов Арктической зоны России: выводы для прогнозирования и поисков новых месторождений». 


\section{Литература}

1. Дистлер В.В. Петролого-геохимические закономерности формирования платиноносных медноникелевых руд // Диссертация на соискание ученой степени д.г.-м.н. Москва. 1985.

2. Дистлер В.В., Гроховская Т.Л., Евстигнеева Т.Л., Служеникин С.Ф., Филимонова А.А., Дюжиков О.А., Лапутина И.П. Петрология сульфидного магматического рудообразования». М. Изд-во: Наука. 1988.

3. Дистлер В.В., Служеникин С.Ф., Кабри Л.Дж, Криволуцкая Н.А., Туровцев Д.М., Голованова Т.А., Мохов А.В., Кнауфф В.В., Олешкевич О.И. Платиновые руды норильских расслоенных интрузивов: соотношение магматического и флюидного концентрирования благородных металлов // Геология рудных месторождений.1999. Т. 41. № 3. С. 241-265.

4. Генкин А.Д., Дистлер В.В., Гладышев Г.Д., Филимонова А.А., Евстигнеева Т.Л., Коваленкер В.А., Лапутина И.П., Смирнов А.В., Гроховская Т.Л. Сульфидные медно-некелевые руды норильских месторождений. М. Изд-во: Наука. 1981.

5. Налдретт А.Дж. Магматические сульфидные месторождения медно-никелевых и платиновых руд.// Санкт-Петербург. Изд-во: СПбГУ. 2003.

6. Служеникин С.Ф. Платино-медно-никелевые и платиновые руды Норильского района и их рудная минерализация // Российский химический журнал. № 2. Т. 54. 2010.

7. E. Mansur, S. Barnes, C. Duran, S. Sluzhenikin. Distribution of chalcophile and platinum-group elements amoung pyrrhotite, pentlandite, chalcopyrite and cubanite from the Noril'sk-Talnakh ores: implications for the formation of platinum-group minerals // Mineralium Deposita, published online, 29 November 2019. 